\title{
Importance of Internal Marketing for Service Companies Corporate Reputation and Customer Satisfaction
}

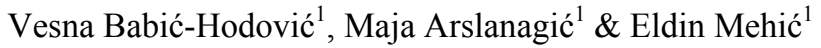 \\ ${ }^{1}$ School of Economics and Business Sarajevo, University of Sarajevo, Sarajevo, Bosnia and Herzegovina \\ Correspondence: Maja Arslanagić, School of Economics and Business Sarajevo, University of Sarajevo, Sarajevo, \\ $\mathrm{BiH}, \quad \operatorname{Trg}$ oslobodjenja - Alija Izetbegovic 1, 71000 Sarajevo, BiH. Tel: 387-61-507-070. E-mail: \\ maja.arslanagic@efsa.unsa.ba
}

Received: March 26, 2013

Accepted: April 12, 2013

Online Published: April 15, 2013

doi:10.5430/jbar.v2n1p49

URL: http://dx.doi.org/10.5430/jbar.v2n1p49

\begin{abstract}
The aim of this paper is to measure customer-based corporate reputation (CBCR) of service companies and to analyze importance of internal marketing within this construct. Research was conducted in Bosnia and Herzegovina and therefore customer-based corporate reputation is put in a specific cultural context. Convenient sampling method was used to gather responses from individual consumers. Apart from descriptive and one-dimensional statistic instruments, collected data were analyzed through exploratory factor analysis. Causality between variables was tested through correlation and OLS regression analysis. This research provided more insights into interconnection of two important constructs for service companies: corporate reputation and internal marketing. CBCR measure incorporates "customer orientation" and "good employer" dimensions which we classified as internal marketing elements. Results showed that elements of customer-based corporate reputation have positive and significant influence on customer satisfaction. This demonstrates that internal marketing represents an important component in building corporate reputation and that it influences customers' perception and their satisfaction.
\end{abstract}

Keywords: Corporate reputation, Internal marketing, Services, Customer satisfaction, Loyalty

\section{Introduction}

Corporate reputation is an important element of identity and it represents a component of company's value on the market. Reputation, image or prominence that company enjoys in public represents in its essence an intangible value that emerged as a result of development, business decisions and past actions of the company. Recently, Walsh and Beatty (2007) defined customer-based corporate reputation (CBCR) construct which takes customer lens to measure reputation construct. They define five dimensions of CBCR: customer orientation, relationship towards employees (internal orientation at the employees) expressed through the good employer' category, reliability and financial strength, products/service quality and social and environmental responsibility.

Role and importance of reputation increases significantly in service companies whose intangible offer (Bromley, 2001; Lovelock, 1999; Shostack, 1982; Parasuraman, Zeithaml \& Berry, 1985) affects the higher uncertainty and decision making risk in pre-purchase phase (Walsh et al., 2009) and the higher insecurity of potential customers as well. As one of the only two visible variables service customers may use for comparing available alternatives (Zeithaml, 1981), corporate reputation, in the analysis of attributes for assessing service alternatives sometimes also defined as corporate image (Hoffman \& Bateson, 1997), becomes a very important factor for the perception of service quality and afterwards for customer satisfaction. This is why the main aim of our paper is to examine the relationship between dimensions of CBCR and customer satisfaction, and to see the importance of each dimension in these relationships.

Increase of employee and customer participation in service interaction, that is, the extension and complication of processes in services is a significant turning point when we observe service companies. This is the characteristic of high contact services (Nguyen \& Leblanc, 2001; Lovelock, 2000). Reputation is an externally perceived category (for customers) that is mostly out of company's control (Fombrun \& Shanley, 1990). However, contact employees in high-contact services play significant role for the process of creating reputation. Additionally, positive corporate reputation significantly increases company's credibility amongst the potential customers (Gregori, 2001). Therefore, special focus is put on the analysis of the importance of internal marketing and the role of employees within CBCR 
construct.

Paper is organized as follows: firstly a literature review on corporate reputation is given making distinction between corporate reputation and employees ("internal customers") and corporate reputation and external customers. This led us to conceptualization of our main research question. Then the methodology of the paper was presented, followed by results and discussion. Finally, conclusion with practical recommendations as well as with recommendations for further research is given.

\section{Corporate Reputation}

Authors often define corporate reputation as a collective impression about the company, internally from the side of employees and externally from the side of other interest groups (Fombrun \& Van Riel, 1997; Walker, 2010). Thereby, Wartick's (2002) emphasis on the fact that reputation of a company or of an individual could not be anything else but the observers' perception should not be forgotten. He defines reputation as stakeholders' perception of companies' success in satisfying demands and expectations of its interest groups (Wartick, 1992; Logsdon \& Wood, 2002). This understanding implies the fact that each individual formulates his/hers individual perception and attitude about the company and its activities. This is much more acceptable for services and service interactions customers assess in the so-called 'moments of truth' (Albrecht \& Zemke, 1985).

At the same time, it is important to stress that different dimensions of corporate reputation could be perceived differently, depending on the subject that is perceived, and on the importance certain dimensions are given and criteria that are used (Dowling, 1988; Walsh \& Beatty, 2007; Fombrun \& Wiedmann, 2001). Authors mostly represented the viewpoint that there are relatively homogeneous attitudes on corporate reputation within certain interest groups (Brown, 1998; Bromley, 2002), although some researches (Helm, 2006) showed that there is significant overlapping within the dimension different stakeholders assess as important for corporate reputation. Hence, for the purpose of this paper, we follow the definition given by Walsh and Beatty (2007:129): "We define customer-based reputation as the customer's overall evaluation of a firm based on his or her reactions to the firm's goods, services, communication activities, interactions with the firm and/or its representatives or constituencies (such as employees, management, or other customers) and/or known corporate activities".

Although some authors (Gatewood et al., 1993) emphasize the need to measure corporate reputation separately, depending on the role that certain stakeholder has for the company and on their relationship with the company, the fact is that different dimensions of relationship the company is creating towards the key stakeholder cannot be separated. Previous research (with the exception of Walsh et al., 2007; 2009) paid insufficient attention towards the basic dimensions of corporate reputation from the perspective of final customers (end users) whose reaction and behavior are significantly influenced by corporate reputation, specially because of the characteristics of services and complexity of their nature. The concept of the paper is based on the assumption that perception of corporate reputation amongst customers and their satisfaction are most influenced by service experience (Grönroos, 1985) and interaction with company and employees, together with the dimensions of corporate reputation which have other stakeholders in their focus. In addition, it is necessary to take into account the multidimensionality of customer category in service industries when analyzing customer perceptions. This is the reason why we structured the following part of the paper by separating external customers and internal customers (employees). Position of employees in services is extremely important for successful interaction with external customers, ensuring high service quality and for implementation of customer orientation as well.

The Method section describes in detail how the study was conducted, including conceptual and operational definitions of the variables used in the study, Different types of studies will rely on different methodologies; however, a complete description of the methods used enables the reader to evaluate the appropriateness of your methods and the reliability and the validity of your results, It also permits experienced investigators to replicate the study, If your manuscript is an update of an ongoing or earlier study and the method has been published in detail elsewhere, you may refer the reader to that source and simply give a brief synopsis of the method in this section.

\subsection{Corporate Reputation and External Customers}

Together with other elements (external marketing of service companies, previous experience and Word of Mouth) customers are exposed to (Gummesson, 1993) corporate reputation will influence formation of previous expectation and according to them - final perception of the process (Boulding et al., 1993; Johnson et al., 1995; Yoon et al., 1993; Zeithaml et al., 1985; Grönroos, 2000). Sivadas and Baker-Prewitt (2000) defined satisfaction and its influence on readiness for spreading positive word of mouth, but they didn't establish direct influence on loyalty. This stresses that satisfaction is 'accelerating' loyalty formation up to the level where it becomes a prerequisite for maintaining a 
positive relationship towards the service provider and customers' readiness for repeat purchase and for making recommendations. If we take a look at the aforementioned definition that Walsh and Beatty (2007) use for customer-based corporate reputation, it could be seen that satisfaction defined as such is 'matching' the reputation company has among its customers.

Although previous research was mostly focused on different stakeholders (Doney \& Cannon, 1997, Fombrun et al., 2000), only Walsh et al. (2007, 2009), put significant accent on customers and their perception of corporate reputation, as the key factor for realization of customer-based outputs and consequently positive financial results. Research on customer perception is imposed as the most important category because of the higher degree of 'decision-making freedom' they have in comparison to employees and even with managers and shareholders. Customer decisions are directly reflected on financial result and market position in the short and especially in the long-term and there are commonly no restraints that tie them to the service company (with the exemption of banking or insurance services). Each decision on the change of service provider will be negatively reflected on the company operations. Monitoring customer perception is made more complicated by the fact that customer requests are becoming higher and higher and their decision making criteria more and more comprehensive. It is often because they endeavor to create the image of themselves as responsible consumers (Kotler \& Lee, 2005; Dawkins \& Lewis, 2003).

Finally, perception of service companies as ones that efficiently and effectively manage their resources and are being profitable (Cole, 2003; Marcus \& Wallace, 1997; Loew et al., 2004) also represents an important dimension of customer-based corporate reputation. These companies guarantee to customers the ability to remain on the market and to expand their operation as well as to follow the development and changes on the demand side.

\subsection{Corporate Reputation and External Customers}

Characteristics of service industry are increasing importance of employees in the service process and perception that customers are forming about companies' in service interactions and direct contact. In line with the development of service industry, importance of internal marketing increases (Voima \& Grönroos, 1999). That is also the case with activities companies use to prepare employees for the role that is intended for them. In this context, increasing the responsibility and the support that management is offering to the employees (Bowen \& Lawler, 1992; Haltier \& Ferrell, 1996) becomes the key for realization of the customer orientation. In the same time, acting on the harmonization of different departments in the company (Lovelock, 1990) becomes a factor that is enabling implementation of customer focus in interactive marketing (Irons, 1997).

In the analysis of customer-based corporate reputation, relationship between an individual and organization is extremely important (Dowling, 2001; Bitner et al., 1997) and it is established via employees at all levels of interaction in services. This is why the way in which customers perceive the relationship of company with employees (Burke et al., 2005) becomes an important dimension of corporate reputation. Customer asses this relationship through company's ability to manage service processes and problems that appear, through its success in resolving spotted problems or the so-called service recovery and through the ability to lead and realize customer orientation. This is why the abovementioned categories, besides quality perception, will directly influence customer-perceived corporate reputation. Key arguments support the view that it is appropriate to check the perception customers have of the company relationship towards its employees.

Although variables that are describing management relationship towards employees (Walsh et al. 2007), described in the form of 'good employee' include dimensions important for employees as one of the most important stakeholder, if not the most important one (Burke et al., 2005; Babić-Hodović, 2010), this dimension is not set up wide enough. Namely, the company's relationship towards its employees is beyond the framework of 'good employee' and it includes results and success on the internal market, through the realization of internal mission and strategy of internal marketing. This concept is based on the relationship between employee satisfaction and customer satisfaction (Heskett et al., 1994.) and service climate (Schneider, 1980) that is enabling the implementation of customer orientation (Jaworski et al., 1993). This is why the analysis of customer-based corporate reputation needs to pay a specific attention to the 'internal customers and internal market' - employees in service companies. Their role in providing quality services and in implementing the customer orientation is crucial. (Schneider \& Bowen, 1992; Judd, 2003).

In line with all stated in the review of relevant literature, and starting from key interest groups companies are faced with, Walsh and Beatty (2007) defined five inter-related dimensions of corporate reputation: customer orientation, relationship towards employees (internal orientation at the employees) expressed through the category 'good employer', reliability and financial strength, (products) and service quality and social and environmental 
responsibility. With the aim of investigating the impact of corporate reputation on customer satisfaction, these dimensions are analyzed from the customer perspective and following research question was posed:

RQ: How do the five dimensions of customer do based corporate reputation influence customer satisfaction?

\section{Methodology}

Research was conducted in Bosnia and Herzegovina and therefore, customer-based corporate reputation is put in a specific cultural context. A convenient sampling method was used to gather responses from 199 individual consumers. Responses were collected through an online survey. The level of agreement with given statements was assessed using a seven-point Likert-type scale, with the anchors "strongly disagree" as 1 and "strongly agree" as 7.

Within our survey, customers were able to select one out of three service industries: banking services, GSM services and fast-food restaurants services. As research was aimed primarily at service sector, these types of services, although different in essence and in core need they satisfy, were selected because they belong to the type of service where there is low to medium interaction (low to medium contact), but however, they include contact between customers and service provider employees (Walsh \& Beatty, 2007; Bowen 1990). According to Walsh and Beatty (2007) three contexts represent less customized service firms. In such firms it is more likely that customers will rely on corporate reputation to relay favorable impressions (Snow and Skaggs 2004). The level of the risks in those three types of services is lower from customer point of view, since all of them belong to the property processing services (Lovelock 2000). Even though, perceived risk is significantly higher for the banking services than the GSM and fast food restaurant ones. For "regular service" (even the banking ones) customer are able to evaluate service process and output without problems. Finally, all services are the ones most of the customers use regularly so they can compare differences between employees' and companies' attitudes and success in the service process. Customers' experience, together with WOM and company's reputation are forming expectations before the service process. However, previous experience in different services delivered form different providers, form accumulated experience which improves customer's knowledge as well as expertise.

Scales that were developed and validated in marketing theory were adopted for the purpose of survey implementation. Customer-based corporate reputation construct was interpreted through Walsh and Beatty (2007) scale and their proposed five dimensions. These dimensions are: customer orientation (CO), good employer (GE), reliable and financially strong company (RFS), service quality (SQ), and social and environmental responsibility (SER). For the purpose of this research, the shorter version of scales was used (Walsh et al., 2009). Customer satisfaction (CS) was measured as a consequence of customer-based corporate reputation (Maxham \& Netemeyer, 2009). In order to give an answer to our research question collected data were analyzed through PCA and OLS regression. Customer based corporate reputation is observed as a set of first-order constructs, not on a second-order level.

\section{Results}

Overall sample of respondents is in the age group from $16-35$, so we can say that the research included younger population. Sample is female dominant $(61 \%)$ and $88 \%$ respondents have university/college degree or higher. Vocational distribution is wide and each category we proposed has its share. When answering the survey, participants were given an option to choose one of the three industries to give their answers for: GSM, Banking and Fast-food. These specific service industries were selected in Bosnia and Herzegovina $(\mathrm{B} \& \mathrm{H})$ because it was aimed at the ones that have developed market and competitiveness within. Most participants in the survey selected GSM operators as their industry of choice (49\%), while the rest of the sample shared its selection more or less equally between the banking (23\%) and fast-food (28\%) industry.

Before testing the influence of dimensions of customer-based corporate reputation on customer satisfaction as the main outcome variable in this research, factor analysis was conducted and in that manner the scale was once more validated on the $\mathrm{B} \& \mathrm{H}$ market. Principal component analysis (PCA) was conducted and results of the analysis are summarized in Table 1 below.

PCA showed that all dimensions of customer-based corporate reputation have high loadings and average variance extracted $68 \%$ and more in all cases. Scale reliability was also tested through Cronbach's alpha which were over 0,70 in all cases. The analysis above enabled us to operate with five (assumed) distinct dimensions of customer-based corporate reputation: customer orientation (CO), good employer (GE), reliable and financially strong company (RFS), service quality (SQ), and social and environmental responsibility (SER). Customer satisfaction was also analyzed through PCA and one dimension was extracted. 
Table 1. Factor analysis output

\begin{tabular}{|c|c|c|c|c|c|c|c|}
\hline & Factor & Item & Loadings & AVE & KMO (Bartlet's Test) & $\alpha$ & Overall $\alpha$ \\
\hline \multirow{15}{*}{$\begin{array}{c}\text { Dimensions of } \\
\text { customer-perceived } \\
\text { corporate } \\
\text { reputation }\end{array}$} & \multirow{3}{*}{$\mathrm{CO}$} & $\mathrm{CO} 1$ & 0,889 & 0,83 & $0,719(371,516)^{* * *}$ & 0,899 & 0,933 \\
\hline & & $\mathrm{CO} 2$ & 0,943 & & & & \\
\hline & & $\mathrm{CO} 3$ & 0,906 & & & & \\
\hline & \multirow{3}{*}{ GE } & GE1 & 0,859 & 0,69 & $0,599(200,373)^{* * *}$ & 0,767 & \\
\hline & & GE2 & 0,915 & & & & \\
\hline & & GE3 & 0,712 & & & & \\
\hline & \multirow{3}{*}{ RFS } & RFS1 & 0,842 & 0,68 & $0,680(154,384)^{* * *}$ & 0,771 & \\
\hline & & RFS2 & 0,863 & & & & \\
\hline & & RFS3 & 0,779 & & & & \\
\hline & \multirow{3}{*}{ SQ } & SQ1 & 0,842 & 0,79 & $0,709(304,390)^{* * *}$ & 0,87 & \\
\hline & & SQ2 & 0,92 & & & & \\
\hline & & SQ3 & 0,91 & & & & \\
\hline & \multirow{3}{*}{ SER } & SER1 & 0,852 & 0,73 & $0,698(199,682)^{* * *}$ & 0,815 & \\
\hline & & SER2 & 0,889 & & & & \\
\hline & & SER3 & 0,823 & & & & \\
\hline \multirow{3}{*}{$\begin{array}{l}\text { Customer } \\
\text { Satisfaction }\end{array}$} & \multirow{3}{*}{$\mathrm{CS}$} & $\mathrm{CS} 1$ & 0,936 & 0,68 & $0,550(314,812)^{* * *}$ & 0,73 & \\
\hline & & $\mathrm{CS} 2$ & 0,946 & & & & \\
\hline & & CS3 & 0,536 & & & & \\
\hline
\end{tabular}

Notes: Extraction Method: Principal Component Analysis; AVE=Average Variance Extracted; $\mathrm{KMO}=$ Kaiser-Meyer-Olkin Measure of Sampling Adequacy; $\alpha=$ Cronbach's Alpha; *** $p<0,001$

Then we proceeded to the core phase of our analysis: answering the research question. In order to empirically test the relationships between CBCR dimensions and customer satisfaction, we used OLS regression analysis with customer satisfaction (CS) as a dependent variable. Model and regression scores are presented in the Table 2 below.

Table 2. Regression scores

\begin{tabular}{ll}
\hline Independent Variable & Model \\
\hline Customer Orientation (CO) & $\mathbf{0 , 3 4 4 * * *}(0,063)$ \\
Good Employer (GE) & $-0,97(0,065)$ \\
Reliable and Financially Strong Company (RFS) & $0,113^{*}(0,66)$ \\
Service Quality (SQ) & $\mathbf{0 , 2 9 7 * * *}(0,087)$ \\
Social and Environmental Responsibility (SER) & $\mathbf{0 , 2 4 6 * * * ( 0 , 0 7 2 )}$ \\
$\mathrm{R}^{2}$ (Adjusted $\mathrm{R}^{2}$ & $0,637(0,626)$ \\
$\mathrm{F}$ & $55,133^{* * *}$ \\
Durbin-Watson residuals correlation test & 1,846 \\
\hline
\end{tabular}

Customer Satisfaction (CS) is dependent variable; Std. errors are shown in brackets

*** Significant at the 0.001 level; ** Significant at the 0.01 level; * Significant at the 0.1 level; $\mathrm{n}=199$ 
Regression results showed relationship between individual constructs of CBCR and customer satisfaction. The overall model was explained with the relatively high coefficient of determination (adj. R2 is equal to 0,626 ). This is especially significant when we observe that these are all intangible elements of corporate reputation. Durbin-Watson ruled out the correlation between the residuals with an acceptable value of 1,846 . When it comes to the relation of the independent variables with the target one, three out of five dimensions showed to be significant at 0,001 level and in their direction positive influencing customer satisfaction. These are customer orientation, service quality and social and environmental responsibility. Importance of the reliable and financially strong company dimension was also confirmed but with a low significant level $(0,1)$ and the fifth analyzed dimension, good employer showed to be non-significant and in its direction negative towards customer satisfaction.

\section{Discussion}

Customer-based corporate reputation is a recently developed approach which is concerned with extracting the best measures for the perception of corporate reputation by one of the most important stakeholder groups - customers. This research used the proposed framework and scale developed by Walsh and Beatty (2007) and through factor analysis confirmed the existence of five distinct dimensions of corporate reputation perceived by customers. Theoretically, the contribution of this analysis is in separating these dimensions into ones targeted at external customers and ones targeted at internal customers (employees). The first group is reserved for quality dimension (SQ), social and environmental responsibility dimension (SER) and for perception of reliability and stability (in financial terms) of the observed company (RFS). The second group is, especially for services, built on an internal market - through the efforts toward employees: customer orientation (CO) and good employer (GE). One of the concerns that could be raised is how customers can asses or perceives the customer orientation or good employer dimension. This is relatively easy to explain in services, and especially in high contact services, because customer here becomes a part of service delivery process and in direct communication with employees he/she gets familiar with the extent of $\mathrm{CO}$ and can form his/her perception about the employer status of the company observed. When it comes to practical implications of this paper, we would like to outline that our main aim was to draw the attention of managers to the underlying components of corporate reputation. We regard that employee satisfaction and perception of a company as a good employer is specifically important category for the corporate reputation, which has been unfairly neglected. Especially in services, companies should build their reputation with the help first line employees. Dissatisfaction of employees ruins the perception of "good employer" and hence has a potential to ruin corporate reputation.

Importance and purpose of the five observed dimensions could not be analyzed by observing them per se. Therefore, a customer outcome variable needed to be selected. Out of the several suggested and already used variables, customer satisfaction was selected (Davies et al., 2002; Walsh et al., 2006, Walsh and Beatty, 2007). Expectedly, all the dimensions classified as the ones targeted at 'external' customers (SQ, SER, RFS) showed to have positive and significant influence. However, when it comes to the dimensions targeted at 'internal' customers, only customer orientation dimension showed to be of significant and positive influence. Good employee dimension doesn't have a significant effect on customer satisfaction. This could be interpreted again through the type of service and possible influence of industries selected. Possible lack of high contact service encounter (as it is true for GSM operators which took over almost $50 \%$ of the sample) could undermine customers' ability to perceive this dimension as an important one for its own satisfaction or they are simply more interested in companies' attitudes and actions focused towards them (customers) than to the employees. Here we have another proof that corporate reputation is important for customer behavioral variables and outcomes, in the first line for customer satisfaction. Hence and in line with resource based view, companies need to regard their reputation as an asset that ensures them competitive advantage.

There is another possible reason for the fact that GE has no significant influence on CS. B\&H is the transitional country where customers are not strongly convinced that they "have rights" to ask companies to fulfill their requests. $\mathrm{CO}$ starts to be evaluated as important factor thanks to the regional and global competition companies' presence. But, even now, there is significant level of defeatism when CS comes to discussion. On the other hand, high level of unemployment in B\&H and the region influence customers' perception strongly. GE becomes each company which "gives jobs". All other dimensions of employment hence become less relevant. And finally, structure of industries customers evaluated, influenced the results. Since more than a half of answers are related to the GSM services and since customers perceive those operators as very attractive employers, giving their staff's high salaries, this factor could not be strong as the others in customers' satisfaction formulation. Sometimes it could even have a contrary effect - when employees are rude or without empathy, no matter the fact that the main reason for their "good jobs is customers' money". 


\section{Conclusion}

This research once again confirmed the importance of corporate reputation as one of the intangible elements of company's offer. In the specific setting of services industry, its importance increases even more. As reputation is based on the perception, the question was aimed at discovering specific dimensions of that perception and analyzing their importance for customers, as one of the most important stakeholders of the company.

Set up in a specific, transition, economy of Bosnia and Herzegovina, our research confirmed the existence of five specific dimensions of customer-based corporate reputation proposed by Walsh \& Beatty (2007). However, when analyzing the relationship of these dimensions with customer satisfaction, not all dimensions proved to be significant. Specifically, the good employer dimension didn't have the influence on customer satisfaction in our model, which could be explained by specificities of selected service industries. This also calls for re-examining the purpose of this dimension within the model.

As for the limitations of the study, they mostly relate to the sample characteristics and selection of service industries. Probably more generalizable results could be achieved with a larger and more representative sample and with the change of service industry observed. This is also one of the recommendations for further research as well as investigating the influence of customer-based corporate reputation on other customer outcome variables (e.g. word-of-mouth or loyalty etc.). Additionally, it would be interesting to observe the changes in relationship over time through longitudinal study and to see the comparative study from different, though comparable, areas.

\section{References}

Aaker, D. A. (1995). Strategic Market Management, 4th. ed. New York: John Wiley.

Albrecht, K. \& Zemke, R. (1985). Service America, Dow Jones Irwin Professional Publishing.

Babić-Hodović, V. (2010). Marketing usluga: koncept, strategije i implementacija. Sarajevo: Ekonomski fakultet u Sarajevu.

Bitner, M. J., William, T. F., Hubbert, A. R. \& Zeithaml, A. V. (1997). Customer Contributions and Roels in Service Delivery. International Journal of Service Industry Management, 8(3): 193-205. http://dx.doi.org/10.1108/09564239710185398

Bromley, D. B. (2001). Relationship Between Personal and Corporate Reputation. European Journal of Marketing, 35: 316-334. http://dx.doi.org/10.1108/03090560110382048

Bromley, D. (2002). Comparing Corporate Reputations: League Tables, Quotients, Benchmarks, or Case Studies? Corporate Reputation Review, 5: 35-50. http://dx.doi.org/10.1057/palgrave.crr.1540163

Brown, B. (1998). Do Stock Market Investors Reward Companies with Reputations for Social Performance? Corporate Reputation Review, 1: 271-280. http://dx.doi.org/10.1057/palgrave.crr.1540048

Boulding, W., Kalra, A., Staelin, R. \& Zeithaml, V. (1993). A dynamic process model of service quality: From expectations to behavioral intentions. Journal of Marketing Research, 30(1): 7-27. http://dx.doi.org/10.2307/3172510

Bowen, D. E. \& Lawler, E. E. (1992). The Empowerement of Service Workers; What, Why, How and When. Sloan Management Review, 33(3): 31-39.

Bowen, J. (1990). Development of a taxonomy of services to gain strategic marketing insights. Journal of the Academy of Marketing Science, 18(1): 43-49. http://dx.doi.org/10.1007/BF02729761

Burke, J. R., Graham, J. \& Smith, J. F. (2005). Putting the customer second. The TQM Magazine, 1(1): 85-91. http://dx.doi.org/10.1108/09544780510573075

Cole, M. (2003). The New Investor Relations: Expert Perspectives on the State of the Art. New York: Bloomberg Press.

Davies, G., Chun, R., Da Silva, R. V. \& Roper, S. (2002). Corporate reputation and competitiveness. London: Routledge.

Dawkins, J. \& Lewis, S. (2003). CSR in Stakeholder Expectations: And their Implication for Company Strategy. Journal of Business Ethics, 44(2-3): 185-193. http://dx.doi.org/10.1023/A:1023399732720

Dowling, G.R. (1988). Measuring Corporate Images: A Review of Alternative Approaches. Journal of Business Research, 17: 27-34. http://dx.doi.org/10.1016/0148-2963(88)90019-7 
Dowling, G.R. (2001). Creating Corporate Reputations. Oxford: Oxford University Press.

Doney, P.M. \& Cannon, J.P. (1997). An examination of the nature of trust in buyer-seller relationships. Journal of Marketing, 61(2): 35-51. http://dx.doi.org/10.2307/1251829

Fombrun, C. J. \& Shanley, M. (1990). What's in a Name: Reputation-building and Corporate Strategy. Academy of Management Journal, 33: 233-258. http://dx.doi.org/10.2307/256324

Fombrum, C. (1996). Reputation, Boston: Harvard Business School Press.

Fombrun, C. J. \& Van Riel, C. (1997). The Reputational Landscape. Corporate Reputation Review, 1(1): 5-13. http://dx.doi.org/10.1057/palgrave.crr.1540008

Fombrun, C., Gardberg, N., \& Sever, J. (2000). The Reputation Quotient: A Multi-Stakeholder Measure of Corporate Reputation. The Journal of Brand Management, 7: 241-255.

Gatewood, R., Gowan, M. \& Lautenschlager, G. (1993). Corporate Image, Recruitment Image, and Initial Job Choice Decisions. Academy of Management Journal, 36: 414-427. http://dx.doi.org/10.2307/256530

Gregori, A. (2001). Public Relations and Evaluation: Does the Reality Match the Rethoric? Jorunal of Marketing Communications, 7: 171-189.

Grönroos, C. (1985). Internal marketing - theory and practice. In: Bloch, T.M., Block, Upah, G.D. \& Zeithaml, V. (Eds), Services Marketing in a Changing Environment. Chicago: American Marketing Association, 41-47.

Grönroos, C. (2000). Service management and marketing. European Journal of Marketing, 15(2): 3-31.

Gummesson, E. (1993). Quality Management in Service Organizations, New York: ISQA.

Haltier, D. M. \& Ferrell, O. C. (1966). The Management of Customer-Contact Service Employees: An Empirical Investigation. Journal of Marketing, 60(4):51-70.

Helm, S. (2006). Common grounds in the perception of corporate reputation? A comparison of three stakeholder groups. 10th Anniversary Conference on Reputation, Image, Identity and Competitiveness, 25-28.

Heskett, L. J., Joens, O. T., Loveman, W. G., Schlesinger, A. L. \& Sasser, E. W. (1994). Putting the Service-Profit Chain to Work. Harvard Business Review, (March-April): 165-174.

Hoffman, K. D. \& Bateson, E. G. J. (1997). Essential Markeitng Services. Orlando: The Dryden Press

Irons, K. (1997). The marketing of services: A total approach to achieving competitive advantage. London: McGraw-Hill.

Jaworski, B. J. \& Kohli, K. A. (1993). Market Orientation: Antecedents and Consequences. Journal of Marketing, 57: 53-70. http://dx.doi.org/10.2307/1251854

Johnson, M. D., Anderson, W. E. \& Fornell C. (1995). Rational and adaptive performance expectations in a customer satisfaction framework. Journal of consumer research, 21(4): 695-707. http://dx.doi.org/10.1086/209428

Judd, C. V. (2003). Achieving a Customer Orientation Using „People-Power“, the 5th P. European Journal of Marketing, 37(10): 1301-1313. http://dx.doi.org/10.1108/03090560310487112

Kotler, P. \& Lee, N. (2005). Corporate Social Responsibility, John Wiley\&Sons, Inc.

Loew, T., Ankele, K., Braun, S. \& Clausen, J. (2004). Significance of the CSR Debate for Sustainability and the Requirements for Companies, Berlin: Future E. V. and Institute for Ecological Research GMBH (IÖW).

Longsdon, J. M. \& Wood, D. J. (2002). Reputation as an Emerging Construct in the Business and Societ Field: An Introduction. Business Society, 41(4): 364-370.

Lovelock, C.H. (1990). Managing Interactions between Operations and Marketing and their Impact on Customers. In: Bowden, D.E., Chase R.B., Cummings, T.G. \& Associates (Eds) 1990. Service Management Effectiveness: Balancing Strategy, Organization and Human Resources, Operation and Marketing, San Francisco: Jossey-Bass Inc.

Lovelock, C.H. (1999). Developing Marketing Strategies for Transnational Service Operations. Journal of Services Marketing, 13(4/5): 278-289. http://dx.doi.org/10.1108/08876049910282538

Lovelock, C. (2000). Services Marketing - People, Technology, Strategy. Prentice Hall.

Marcus, B. W. \& Wallace, W. S. (1997). New Dimensions in Investors Relations: Competing for Capital in the 21st Century. New York: John Wiley \& Sons. 
Maxham, J., III, \& Netemeyer, R. (2002). A longitudinal study of complaining customers' evaluations of multiple service failures and recovery efforts. Journal of Marketing, 66(4): 57-72. http://dx.doi.org/10.1509/jmkg.66.4.57.18512

Nguyen, N. \& Leblanc, G. (2001). Corporate image and corporate reputation in consumers' retention decision in services. Journal of Retailing and Consumer Services, 8(3): 227-236. http://dx.doi.org/10.1016/S0969-6989(00)00029-1

Parasuraman, A., Zeithaml, V. A. \& Berry, L. L. (1985). A Coneptual Model of Service Quality ad its Implications for Future Research. Journal of Marketing, 49: 41-50. http://dx.doi.org/10.2307/1251430

Schneider, B. (1980). The Service Organization: Climate is crucial. Organizational Dynamics, (Autumn): 52-65. http://dx.doi.org/10.1016/0090-2616(80)90040-6

Schneider, B. \& Bowen, E. D. (1992). Personnel/Human Resource Management in the Service Sector. In: Ferris, G. \& Roland, K. (Eds), Research on Personnel and Human Resources Management, Greenwich: JAI Press, 10: $1-30$.

Shostack, G. L. (1982). How to design a service? European Journal of Marketing, 16(1):49-63. http://dx.doi.org/10.1108/EUM0000000004799

Sivadas, E. \& Baker-Prewitt, J.L. (2000). An examination of the relationship between service quality, customer satisfaction, and store loyalty. International Journal of Retail $\ \&$ Distribution Management, 28(2):73-82.

Snow, C., \& Skaggs, B. C. (2004). The strategic signaling of capabilities by service firms in different information asymmetry environments. Strategic Organization, 2(1): 271-291.

Voima, P. \& Grönroos, C. (1999). Internal Marketing - A Relationship Perspectie. In: Baker, M. J. (ed), The IEBM Encyclopedia of Marketing. London: International Thomson Business Press: 747-751.

Walker, K. (2010). A Systematic Review of the Corporate Reputation Literature: Definition, Measurement, and Theory. Corporate Reputation Review, 12(4): 357-387. http://dx.doi.org/10.1057/crr.2009.26

Walsh, G., Dinnie, K., \& Wiedmann, K. P. (2006). How do corporate reputation and customer satisfaction impact customer defection? A study of private energy customers in Germany. Journal of Services Marketing, 20(6): 412-420. http://dx.doi.org/10.1108/08876040610691301

Walsh, G. \& Beatty, S. E. (2007). Customer-based corporate reputation of a service firm: scale development and validation. Journal of the Academy of Marketing Science, 35: 127-143. http://dx.doi.org/10.1007/s11747-007-0015-7

Walsh, G., Beatty, S.E. \& Shiu, E.M.K. (2009). The customer-based corporate reputation scale: Replication and short form. Journal of Business Research, 62: 924-930. http://dx.doi.org/10.1016/j.jbusres.2007.11.018

Walsh, G., Mitchell, W-V., Jackson, R. P. \& Beatty, E. S. (2009). Examining the Antecedents and Consequences of Corporate Reputation: A Customer Perspective. British Journal of Management, 20: 187-203. http://dx.doi.org/10.1111/j.1467-8551.2007.00557.x

Wartick, S. (1992). The Relationship Between Intense Media Exposure and Change in Corporate Reputation. Business \& Society, 31: 33-49. http://dx.doi.org/10.1177/000765039203100104

Wartick, S. (2002). Measuring Corporate Reputation. Business \& Society, 41: 371-392. http://dx.doi.org/10.1177/0007650302238774

Yoon, E., Guffey, H.J. \& Kijewski, V. (1993). The effects of information and company reputation on intentions to buy a business service. Journal of Business Research, 27(3): 215-228. http://dx.doi.org/10.1016/0148-2963(93)90027-M

Zeithaml, V. A. (1981). How Consumer Evaluation Processes Differ Between Goods and Services. In: Donnelly J. George W. (Eds) 1981. Marketing of Services, Chicago: American Marketing Association, 186-189.

Zeithaml, V., Parasuraman, A. \& Berry, L. (1985). Problems and strategies in the Services Marketing. Journal of Marketing, Spring, 49(2): 33-46. 